$\begin{array}{lllllll}\text { (c) EUSP, } 2018 \quad \mid \mathfrak{e} & \text { ISSN 2310-3817 Vol.6 SICS }\end{array}$
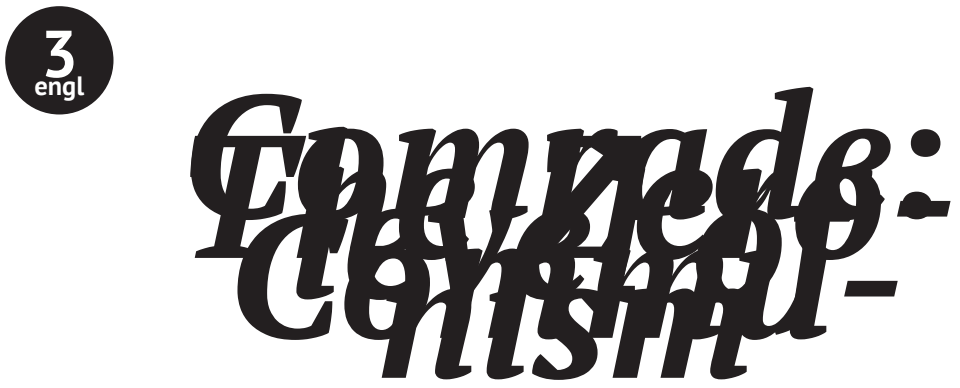

Jodi Dean

Professor of Hobart and William Smith Colleges, Department of Political Science 300 Pulteney Street, Geneva, NY, USA 14456

E-mail:JDEAN@hws.edu

\title{
Comrade: The Zero-level of Communism
}

\begin{abstract}
Drawing from Andrei Platonov's Chevengur, I present the figure of the comrade as the zero-level of communism. Platonov's comrades persist in a postrevolutionary zone without workers, without classes, where the remainders of the old order have nothing but each other. Their condition of deprivation, where the persistence of each depends on the persistence of all, supplies the ground upon which to build communism. The comrade is the zero-level of communism because it designates the relation between those on the same side of the struggle to produce a new set of free, just, and equal social relations, relations without exploitation. Their relation is political, divisive. And it is intimate, intertwined with the sense of how desperately each depends upon the other if all are to persevere. I test this account of the comrade through the counter-intuitive case of the
\end{abstract}


Communist Party of the United States. Although seemingly far removed from the Chevengurian communist project, the CPUSA nonetheless worked to establish the zero-level necessary for the communist movement: comradeship between black and white workers. At the basis of this comradeship was an understanding of

racism as a condition of deprivation to be redressed through deprivation. Racism deprives the working class of solidarity. Solidarity requires that white workers deprive themselves of white privilege, the "wages of whiteness," to use W.E.B. Dubois's term. Hence, the Party focused, for a while, on establishing the zero-level of comradeship by devoting itself to the struggle for racial equality. If solidarity is possible, it is because the abolition of white supremacy leaves comrades to start anew.

\section{Keywords}

comrade, race, Communist Party, communism, Platonov, solidarity

Crucial to the revolutionary legacy of 1917 is the figure of the comrade. Although already established as a term of address in the world socialist movement in the late nineteenth century, "comrade" as an emancipatory egalitarian figure of belonging derives its energy from the Bolsheviks and the early years of the Soviet experiment. In this essay, I am concerned less with the affective and ethical dimensions of the comrade than I am with how the comrade provides the zero-level of sociality necessary for communism. After a brief look at the ideal of comradeship as a sensibility for Alexandra Kollontai and Maxim Gorky, I turn to Andrei Platonov's strange account of comrades in Chevengur. Far from the romantic scene of solidaristic workers brought together in the factory and united against the boss, Platonov's comrades persist in a postrevolutionary zone without workers, without classes, where the remainders of the old order have nothing but each other. Their condition of deprivation, where the persistence of each depends on the persistence of all, supplies the ground upon which to build communism. Anything more is less: once one has property, one attends to that rather than to one's comrades. I then jump to the Communist Party (CP) of the United States. As it tried to build a communist movement in the US, the $\mathrm{CP}$ came up against the white supremacy and racism that not only divided the working class but that permeated every aspect of US society. Although seemingly far removed from the Chevengurian communist project, the CPUSA nonetheless worked to establish the zero-level necessary for the communist 
movement: comradeship between black and white workers. At the basis of this comradeship was an understanding of racism as a condition of deprivation to be redressed through deprivation. Racism deprives the working class of solidarity. Solidarity requires that white workers deprive themselves of white privilege, the "wages of whiteness," to use W.E.B. Dubois's term. Hence, the Party focused, for a while, on establishing the zero-level of comradeship by devoting itself to the struggle for racial equality. If solidarity is possible, it is because the abolition of white supremacy leaves comrades to start anew.

\section{A Feeling of Belongingness}

In her writings on prostitution, sex, and the family from the early years of the Bolshevik revolution, Alexandra Kollontai presents comradeship and solidarity as sensibilities necessary for building a communist society. She associates comradeship with a "feeling of belongingness," a relation among free and equal communist workers (Kollontai 2006 [1918]). Under capitalism, workers are not automatically comrades. Capitalism tries to tear them apart, make them competitive, self-interested and afraid. Communism will abolish these conditions. "In place of the individual and egoistic family, a great universal family of workers will develop, in which all the workers, men and women, will above all be comrades" (Kollontai 1977a [1920]). “Comrade” points to a mode of belonging opposed to the isolation, hierarchy, and oppression of bourgeois forms of relation, particularly of work and the family under capitalism. It's a mode characterized by equality, solidarity, and respect; collectivity replaces egoism and self-assertion. In Russian, the word "comrade," tovarish, is masculine, yet its power is such that it liberates people from the chains of grammar. A Soviet book on literary language published in 1929 gives the example of "comrade sister," a formulation that sounds funny in Russian but evokes the new language and emotions of the revolution. ${ }^{1}$

For Kollontai, comradeship is a core principle of proletarian morality, the key to the "radical re-education of our psyche" under communism. Comradeship engenders new feelings such that people no longer feel themselves unequal and compelled to submit. Now they are "capable of freedom instead of being bound by a sense of property, capable of comradeship rather than inequality and submission" (Kollontai 1977b [1921].

Maxim Gorky has a short story from the early twentieth century, published in English in 1906 in The Social Democrat, simply titled "Com-

I am indebted to Maria Chehonadskih for this example, which comes from the 1929 book by G. O. Vinokur, Kul'tura iazyka [Language culture]. 
rade." The story testifies to the life-giving power of the word "comrade." Gorky presents "comrade" as a word that "had come to unite the whole world, to lift all men up the summits of liberty and bind with new ties, the strong ties of mutual respect." ${ }^{2}$ The story depicts a dismal, "torturous" city, a city of hostility, violence, humiliation, and rage. In this city, the weak submit to the dominance of the strong. In the midst of this miserable suffering, one word rings out: comrade! And the people cease to be slaves. They refuse to submit. They become conscious of their strength. They recognize that they themselves are the force of life.

When people say "comrade," they change the world. Gorky's examples include the prostitute who feels a hand on her shoulder and then weeps with joy as she turns around and hears the word "comrade." With this word, she is interpellated not as a self-commodifying object to be enjoyed by another, but as an equal in common struggle against the very conditions requiring commodification. Additional examples are a beggar, a coachmen, and young combatants - for all, "comrade" shines like a star that guides them to the future.

As with Kollontai, Gorky associates the word "comrade" with freedom from servitude and oppression, with equality. As with her, he presents the comrade as opposed to capitalist egoism's exploitation, hierarchy, competition, and misery. And as with Kollontai, Gorky links comradeship to a struggle for and vision of a future in which all will be comrades.

The joy and courage that comes with "comrade" might suggest that the term's happy strength is naïve, ripe for cynical ideological manipulation, which, after all, is not entirely historically inaccurate. Yet there is a negativity to "comrade" that undermines cynical manipulation. "Comrade" abstracts from given social positions to posit a political relation among those who join together in opposition to a system of oppression. Liberation from the given enables a new form of relation among equals on the same side of a struggle. Platonov's Chevengur opens up the negativity of "comrade."

\section{Enjoy Each Other}

Platonov's presentation of comradeship in Chevengur, the novel he completed in 1928, illuminates the comrade's negativity. ${ }^{3}$ Far from Kollontai's and Gorky's joyful, courageous comrades, Platonov's comrades are destitute masses who have nothing but each other. He presents these masses as new arrivals to Chevengur, the village on the steppe that had

\footnotetext{
I am indebted to Alexei Penzin for bringing this story to my attention.

Chevengur was not published as a novel in Russian until a partial version appeared in 1972. A more complete version was published in 1988 (Jameson 1994: 79).
} 
achieved communism, writing: "the new Chevengurians had no joys before them and none that they expected, and thus they remained satisfied with that which all unpropertied people possess, a life shared with people identical for them, companions and comrades for the roads through which they pass" (Platonov 1978: 243). Comrades here are the zero point of possibility, what is left after everything else is gone, remainders in ruins, the negative place of beginning. Instead of treating comradeship as the relation between the Bolsheviks in his novel, Platonov presents "comrade" like "communism" - both are words in an inchoate postrevolutionary vocabulary of rupture, longing, possibility, and loss. The new world has not arrived, but there are new words, words which don't quite make sense of the present, especially for those living out on the steppes in the last years of the Civil War. Isabelle Garo writes, "In Chevengur, communism is the name of a world that does not exist, which could be constructed and that is already in ruins. It is also a more subjective than objective reality, or rather a principle of subjectivation ..." (2017: 180). Comrade is the relation necessary for the construction of this world, a relation present in and as the absence of property, nationality, and recognizable identity.

More specifically, Platonov highlights the comradeship of the "miscellaneous" or "others," the wandering, propertyless, classless, postrevolutionary, bastard people. Piled in a heap for warmth at the edge of the town, these half-naked, starving, orphaned masses are the poorest of the poor. Their unity is corporeal, the conglomeration of their multiple international bodies. The Russian word translated as "others" or "miscellaneous" is prochie. Maria Chehondadskih explains that prochie was used on early Soviet documents when the class identity of a person was unknowable (2017: 139). Prochie are remnants, mistakes, and remainders, proletarianized even of their class identity. The classless prochie embody the melancholic moment of revolution. ${ }^{4}$ Classes have dissolved. Exploitation has ended. But the new society has yet to be built. The presence of the remaindered others disrupts identitarian logics: not only are they classless but they lack even nationality, "the torment of life and labor too large had rendered their faces non-Russian" (Platonov 1978: 231). One of Chevengur's Bolsheviks sees in these remainders a glimpse of revolutionary potential: "That's a class of the first quality that you've got there. You've just got to lead it forward and it won't so much as squeak. This here is your international proletarians. Just look! They aren't Russian, they aren't Armenian, they aren't Tatars ... they aren't anybody!” (Platonov 1978: 232). The "others" are characterized by loss, by not being anybody at all. The miscellaneous lack a discernible Russian identity - their faces are inter-

$4 \quad$ See Artemy Magun (2013). 
national, faces from nomads and Mongolians. ${ }^{5}$ They lack militancy. ${ }^{6}$ They aren't organized, but their comradeship holds the place for something like a future. Their utter destitution has resulted not in atomized individuals isolated in egoistic self-interest, but in comradeship as the zeropoint of relationality necessary to continue. If communism is possible, it's because the abolition of classes and property leaves comrades to start anew.

The comradeship of the remaindered others is an effect of their destitution. Platonov writes:

[...] the others had built themselves into self-made people of unknown designation; moreover, this exercise in endurance and inner resources of body had created in the others not only a mind full of curiosity and doubt but also a quickness of feeling capable of trading eternal bliss for a comrade who was one of them, since this comrade had no father and no property yet was able to make a man forget about both - and within them the others still bore hope, a hope that was confident and successful but sad as loss. What was precise in this hope was this: if the main thing - staying alive and whole - were successfully accomplished, then everything and anything else remaining would be accomplished, even if it were necessary to reduce the world to its last grave [...] (unpublished translation by R. Chandler, in Chehonadskih 2017: 137). ${ }^{7}$

A comrade lets one forget the status that the world gives them birth, family, name, class. In the absence of these relations, comrades develop a reflex for solidarity that exceeds personal happiness. Likewise commenting on Chevengur, McKenzie Wark writes, "The comrades are the ones with which we share life's task of shoring up its impossible relation to a recalcitrant world. All we can share are the same travails, and we are only comrades when we might all share all of them" (2015: 106). The shared destitution of those who endure contains hope.

There is a strange opposition between the German and Russian words for "comrade." The German Genosse is linked to geniessen, to enjoy. It is associated with the shared use or enjoyment of something, with a common relation to property along the lines of a right of use, usu-

5 Maria Chehonadskih emphasizes that Platonov takes an anticolonial perspective that breaks with the image of a white working class (personal communication).

This lack of militancy distinguishes Platonov's "others" from the "comrades" movement in Natal, South Africa in the late 1980s. In interviews, these young militants expressed "a strong sense of 'having nothing”" (Sitas 1992: 634). Yet in addition to this nothing - no job, no education, no food, no way out - they also had a militarized culture of resistance and a sense of social solidarity.

Compare the translation in Platonov (1978: 231). 
fruct (Bartholmes 1970: 175). ${ }^{8}$ The Russian tovarisch comes from tovar, a good for sale, a commodity-thing. The opposition between these word origins seems clear in Chevengur. Platonov opposes property and comradeship. Acquisition of property leads to the loss of comradeship; people put their energy into things instead of each other. Platonov writes, "When property lies between people, the people calmly expend their powers on worrying about that property, but when there is absolutely nothing between people, then they begin not to part and to preserve one another from the cold as they sleep" (Platonov 1978: 225). Comradeship results from the absence of property, not its shared use or enjoyment. As one of the characters in the novel says, "And I say to you that we are all comrades only when there is identical trouble for everybody. As soon as there is bread and property, why you'll never get a man out of it!" (Platonov 1978: 141).

This initial opposition between the German and Russian origins of "comrade" may be too quick. Platonov's treatment of the prochie introduces another kind of property, the collective self-possession of the unpropertied: "Perhaps these proletarians and miscellaneous served one another as each other's sole possession and worth in life, and thus they looked with such concern at one another, not paying much attention to Chevengur, and carefully kept their comrades free from flies, just as the bourgeoisie had once guarded their homes and livestock" (Platonov 1978: 228). Having nothing but each other, the miscellaneous nevertheless have something, something to protect and care for. The intimate physicality of swiping away flies gives us a comradeship of the destitute where things (tovary) enjoy (geniessen) each other; comrades engage in collective self-enjoyment, collective use of the collective. For there to be communism, comrades have to enjoy each other, refusing to let property take their place.

In Chevengur, the Bolshevik Chepurny worries that women might endanger the preservation of Soviet Chevengur. He thus insists on comrade women, on women to whom men will relate as comrades, not by desires for sex and reproduction. "Chepurny was ready to welcome any woman to Chevengur so long as her face was darkened by the sadness of poverty and the old age of work. Then such a woman would be fit only for comradeship and would create no differences in the midst of the oppressed masses, and probably would not evoke that dispersive love consciousness among the lonely Bolsheviks" (Platonov 1978: 211). Comrade women, like all the remaindered others, are poor, exhausted, sad, and lacking. They are no different from anyone else - that's what makes them comrades.

8 I am indebted to David Riff for first drawing my attention to this point. 
Platonov's melancholic comradeship gives us insight into the formalization of the lack of identity, nationality, class, and property into a political relation. The comradeship of the "others" is not an imaginary plentitude of happiness and well-being. On the contrary, it's the minimal degree of relation necessary for endurance, for hope. Comradeship is a necessary condition for communism: the collective of those who enjoy each other refuse to let property take their place. The negation of identity, nationality, class, and property produces something new, a new space of relation that exerts a pressure of its own. The comrade is the zero-level for communism.

Slavoj Žižek argues that “the zero-level is never 'there,' it can be experienced only retroactively, as the pre-supposition of a new political intervention, of imposing a new order" (2013: 967). In Chevengur, this is born out in the way that the "miscellaneous" are often presented from the perspective of Chepurny's Bolshevik haste to build communism. The narrative voice of the novel deliberately resists localization; it is neither an objective description of facts nor the subjective perception of a single character. ${ }^{9}$ Descriptions of the "miscellaneous" meld into depictions of Chepurny's thoughts and desires and over into his own reflections. For example: "Chepurny sensed how in exchange for the steppe, the houses, the food, and the clothes which the bourgeoisie had acquired for themselves, the proletarians on the mound had each other, because every man has to have something” (Platonov 1978: 225). To Chepurny, those on the mound have not yet appeared as classless others; he sees them as proletarians, as the force that will usher in the future. It's from the position of this communist future - already being built in Chevengur - that the destitution of the remaindered others manifests as comradeship. From the perspective of communism, desolation is not the end - it is an opening to something we couldn't grasp before, in this instance, the presence of something when all is lost, comradeship. The comrade is the zero-level of communism because it designates the relation between those on the same side of the struggle to produce a new set of social free, just, and equal social relations, relations without exploitation. Their relation is political, divisive. And it is intimate, intertwined with the sense of how desperately each depends upon the other if all are to persevere.

\section{Bolshevism as Anti-racism}

The summer of 1919 massive strikes erupted across the US - a general strike in Seattle as well as steel and coal strikes involving hundreds

See Podoroga (1991). 
of thousands of workers. Anarchist bombing campaigns intensified the situation. Black soldiers newly returned from the front received not a hero's welcome, but discrimination, oppression, and violence. They were passed over for good jobs, pushed into menial work. Rioting white people attacked black people. Black people fought back. Lynchings increased across the South. White southerners even burned people at the stake, the state of Mississippi authorizing the burning alive of a black man. The governor claimed that he was powerless to stop it but had been assured that "necessary arrangements" had been made and that the mob would act in conformity to these arrangements. Three thousand people came to watch (Whitaker 2009: 47). The black press - which had over two hundred newspapers - urged black people to protect themselves, to oppose lynch law with "cold steel and fire," with "iron will and inflexible determination" (Whitaker 2009: 49). The headlines of white newspapers screamed "Reds Try to Stir Negroes to Revolt." Blaming the Bolsheviks for the chaos in the US, mainstream white newspapers told their readers that black publications were financed by Russia with the goal of establishing Bolshevik rule in the US. Linking the black struggle for liberation to Bolshevism, the white press made black people who fought back look like traitors. The US Department of Justice started to treat black people "as potential enemies of the state" (Whitaker 2009: 50). White southerners inverted the problem: it was not that Negroes were going to usher in communist domination; communism would lead to Negro domination (Whitaker 2009: 50).

This was the context within which Cyril Briggs boldly claimed the Soviets as allies in the black liberation struggle and anti-bolshevism as a racist attack on black radicalism. One of a number of West Indian immigrants influential in the Harlem Renaissance, Briggs founded the magazine, the Crusader, in September 1918 (Solomon 1998: 6). The magazine was dedicated to "race patriotism," to "Africa for the Africans." Shortly after its start, the Crusader began featuring articles linking capitalism and colonialism as well as promoting a proletarian identity shared by black and white workers (Solomon 1998: 7). Given Briggs's race-first commitments, this was a radical innovation. Briggs was merging revolutionary socialism and black nationalism. During the violent Red Summer of 1919, Briggs presented race as a labor issue. He was not content to echo the black press and emphasize the racial dimension of the violence inflicted on African Americans. He saw the violence as connected to working class struggle. By the end of the year, he was associating anticommunism with white supremacy. Briggs wrote: "That Negro editors and cartoonists should fall for the lies about Soviet Russia put out by the white capitalist press is all the more surprising when it is considered that these same Negro cartoonists and editors are members of a race even more viciously lied about by the same white capitalist press" (Briggs 2018a: 241). 
Anticommunism was contrary to black interests, the ideology of black workers' white capitalist enemy.

At the same time he was publishing the Crusader, Briggs organized the African Blood Brotherhood (ABB). Through both he produced an original synthesis of African identity and Leninist internationalism (Solomon 1998: 13). The synthesis relies in part on Brigg's vision of an originary African communism destroyed by slavery and colonialism. Communism, in this vision, is authentically African - not European. Anchored in the past, Brigg's synthesis is nevertheless oriented to the future: the only path for black liberation is through an independent socialist $\mathrm{Ne}$ gro state within a larger socialist commonwealth. For Briggs, black liberation depends on socialism - the interests of all people of African descent lead to socialism. African freedom is impossible in a capitalist system. Only an anti-imperialist alliance with the broader working class, with black workers leading advanced white workers, will secure the dream of black national independence. The ABB thus presented the black freedom struggle as aiming toward socialist transformation - not "assimilation into the bourgeois order," and it presented black workers as the leaders of multiracial working class, not followers of a black elite (Solomon 1998: 16). The Soviet experiment was a resource, a model, inspiration, and bulwark, in the black struggle for liberation.

In 1921, Briggs joined the Workers Party, one of the two parties that would merge to become the Communist Party. He nonetheless continued to work through the ABB and publish the Crusader. The platform of the Workers Party included Briggs's insights into "the role of slavery and lynch terror in the nation's accumulation of capital" and "the use of racial prejudice to subject blacks to extreme exploitation and to divide the working class" (Solomon 1998: 20). The Workers Party committed itself to destroy race prejudice and bind black and white workers into a union of revolutionary forces (Solomon 1998: 21). In the Crusader, Briggs took up the question of "white friendship." Black people had been "grievously deceived" by past white declarations of friendship that ended up being for "personal gain or the curbing of Negro 'radicalism"” (Briggs 2018b: 263). So black workers had good reason to be skeptical about uniting with whites. Nevertheless, Briggs argues, black workers should recognize that white workers need black help to attain their goals. And white workers' need is politically useful: "There are schisms in the white race which, by encouraging, we can ultimately benefit ourselves" (Briggs 2018b: 264). Black workers should not let the fact and fear of white opportunism hinder an analysis that can advance the black cause. Even more, black and white workers can be comrades. Briggs writes, "Already white men have fought together with Negroes in defense of their common interests, and have staunchly refused to accept divisions in their ranks and betray their Negro comrades, although white employers have offered 
to concede to the workers' demands in the case of white workers if the latter would betray their Negro comrades" (Briggs 2018b: 263-64). Briggs proposes an acid test for black workers seeking to determine whether to work with whites: Is a white person "willing to see the Negro defend himself with arms against aggression, and willing even to see Negroes killing his own (white) people in defense of Negro rights?” (Briggs 2018b:264).

By the early 1930s, US Communists were taking this test seriously. Historian Mark Solomon gives the example of the instructions given by a Communist Party organizer in 1932. Visiting a section, the organizer

told the group that Negroes had been betrayed perennially by whites seeking their support: what every Communist must do is to be willing to die in defense of any Negro's rights, and it doesn't have to be anything flamboyant or very important - any insult, and there are plenty, directed by a white person against a Negro, is reason enough for a Communist to react, to slap his or her face, hit hard and if you be killed, that's alright too, because [...] without the Negro people we are only treading water as far as making the revolution in the US (Solomon 1998: 135).

The zero-level of black-white comradeship is white willingness to die. If they wanted to build class unity, white communists had to prove to black people that they would defend the commitment to black liberation - Negro rights in the language of the 1930s Party organizer - to the death. Anything less would put them on the side of racism, lynching, and Jim Crow exclusion from decently waged jobs. In effect, white communists would have to give up their property in whiteness, abolish their own racial ignorance and privilege, if they wanted to create the conditions of possibility for unifying the working class. The advance of the white working class cannot come at the expense of black life. They can only persevere together.

\section{The Black Belt Thesis}

The practical organizational life of CPUSA from the late 1920s through the mid-1930s was frought, conflictual. Responding to criticisms from African American Communists that their white comrades were insufficiently engaged in organizational work within the black community, the Comintern pushed the Party to eliminate white chauvinism from its ranks and elevate the "Negro question" to the center of its organizing. At the same time, there were real dangers to interracial organizing in the Jim Crow South. These conditions - class struggle under white supremacy - illuminate the position of the comrade as the zero-level of commu- 
nism. The scandalous Black Belt thesis illustrates this point.

After several years of debate, the Comintern and thus the Communist Party took the position that black people in the Black Belt of the US (a large swathe of majority black counties in the south, called the Black Belt because of the rich, dark soil) constituted an oppressed nation with the right to self-determination. I call this thesis "scandalous" because it is often denigrated as out of touch with reality, dogmatic, ludicrous, impossible, etc. - even as it echoed the nationalist themes of Marcus Garvey's United Negro Improvement Association and was picked up more than thirty years later by African American revolutionaries. ${ }^{10}$ The thesis also appears scandalous when put up against workerist assumptions that communists privilege the class struggle above all other struggles. Opposing the thesis in 1939, C.L.R. James argues that "for us to propose that the Negro have this black state for himself is asking too much from the white workers, especially when the Negro himself is not making the same demand. The slogans of 'abolition of debts', 'confiscation of large properties', etc, are quite sufficient to lead them both to fight together and on the basis of economic struggle to make a united fight for the abolition of social discrimination" (Trotsky 1940). Of course, James was not in the Communist Party. His statement was prepared for a meeting he had with Trotsky. Even in the CP, though, there was initial opposition to the idea that black people constituted an oppressed nation from those who insisted that the issue was racial not national.

In his memoirs, Black Bolshevik, Harry Haywood, the primary force behind the Black Belt thesis, sets out the stakes of the debate. The first issue was how to think about African Americans. Were they an oppressed racial minority or an oppressed national minority? The "national minority" position employed a theory of the nation developed by Stalin. Haywood presents Stalin's definition of a nation as

a historically constituted stable community of people, based on four main characteristics: a common territory, a common economic life, a common language, and a common psychological makeup (national character) manifested in common features in a national culture. Since the development of imperialism, the liberation of the oppressed nations had become a question whose final resolution would only come through proletarian resolution (Haywood 1978: 157).

Already in 1920, Lenin had proposed to the Comintern a resolution stating that black people in the US constituted an oppressed nation (Haywood 1978: 219). Under conditions of imperialism, the struggles of op-

10 Cedric J. Robinson criticizes the thesis as opportunist and anchored in an incoherent notion of the nation (2000: 226). See also Tomek (2012). 
pressed nations were objectively revolutionary. There was no contradiction between national and proletarian struggles. The liberation of oppressed nations, overthrow of imperialism, and achievement of socialism were interdependent, each requiring the other.

Haywood, after numerous conversations with his friends and comrades at the Lenin School in Moscow, developed an historical analysis to support viewing black people in the US as an oppressed nation. In brief, African American history begins in slavery and continues through the Civil War and betrayal of Reconstruction. This betrayal unleashed "counter-revolutionary terror, including the massacre of thousands of Blacks" (Haywood 1978: 231). Denied the land that should have been theirs had the plantations been confiscated and broken-up, black people were reduced again to conditions of near chattel slavery. Imperialism, the stage of capitalism characterized by monopolies, trusts, and financial oligarchy, "froze" black people into their "landless, semi-slave" position, "blocked the road to fusion of Blacks and whites into o229ne nation on the basis of equality and put the final seal of the special oppression of Blacks" (Haywood 1978: 231-32). Imperialism and racist oppression thus produced those conditions in the South under which black people across the US became a subject nation. Haywood writes: "They are a people set apart by a common ethnic origin, economically interrelated in various classes, united by a common historical experience, reflected in a special culture and psychological makeup" (1978: 232). Their national territory is the Black Belt, where they constitute a majority.

Those who considered African Americans to be an oppressed racial minority took any expression of black nationalism to be reactionary, a diversion from the primary struggle of organizing blacks as workers. They saw "'pure proletarian struggle' class struggle as the sole revolutionary struggle against capitalism” (Haywood 1978: 229). Haywood reports that black comrades from CPUSA offered some of the most vehement criticisms of the idea that black people constituted an oppressed national minority. Rejecting the claim that black people were oppressed as a nation, James Ford argued that there was no systemic economic separation between whites and blacks, only racial differences of skin color. Otto Hall (Haywood's brother) said that class interests so divided black people that they could not be considered a national entity and besides, their primary goal was assimilation.

The second issue of political tactics followed closely from the debate over nation or race. Haywood argues that the emphasis on racial prejudice not only fails to grasp the revolutionary nature of national liberation struggles (which Lenin had already articulated) but also fails to provide a position from which to combat white chauvinism in the party and among the white working class. Haywood is particularly concerned that his black US comrades separate racism "from its socio-economic 
roots, reducing the struggle for equality to a movement against prejudice” (1978: 264). To emphasize race rather than nation is to "downgrade the revolutionary nature of the Black struggle for equality" (Haywood 1978: 264). Such an emphasis requires no radical change (land reform and democratic power in the South). It results instead in a bourgeois assimilationist struggle against prejudice and an effort to bring black and white workers together. In contrast, the self-determination line, Haywood explains:

established that the Black freedom struggle is a revolutionary movement in its own right, directed against the very foundations of U.S. imperialism, with its own dynamic pace and momentum, resulting from the unfinished democratic and land revolutions in the South. It places the Black liberation movement and the class struggle of the U.S. workers in their proper relationship as two aspects of the fight against the common enemy - U.S. capitalism. It elevates the Black movement to a position of equality in that battle (Haywood 1978: 234).

With this line, the $\mathrm{CP}$ would no longer make the mistake of subordinating the black struggle to the class struggle. Instead, the party would have to educate white workers about the revolutionary role of the black liberation struggle. As an article in the Daily Worker instructs, "it is the duty of the Communist Party of the U.S.A. to mobilize and rally the broad masses of the white workers for active participation in this struggle" ("Black Belt Thesis" 2018: 383). ${ }^{11}$ White comrades would have to make black struggle their own - anything less would be a betrayal of the revolution.

Against those who treated black self-determination in the Black Belt as a formula for separatism, Haywood demonstrates its function in building unity. The class consciousness of white workers can only be race consciousness - white chauvinism - if they are not fully committed to the abolition of race hatred, Jim Crow, lynching, prejudice and "even indifference" to the Negro struggle ("Black Belt Thesis" 2018: 287). Within the Party race prejudice has to be weeded out and eliminated, "fought with the utmost energy" ("Black Belt Thesis" 2018: 286). As Mark Solomon observes, the self-determination line committed the party to fighting for the right of black people "to be free to control the political and social lives of their communities;" at the same time, it redefined "the conception of black-white cooperation on the basis of new power relationships among equals" (Solomon 1998: 86).

The Black Belt thesis put the black comrade in the position of "ego ideal." Solomon writes, "for the dedicated Communist there was no escape from excruciating self-examination" (1998: 135). Comrades had

11 Originally published in the Daily Worker, February 12, 1929. 
to see themselves from a new perspective - not simply that of equals on the same side in the class struggle but that of equals on the same side of a national liberation struggle, equals fighting against the oppression of a national minority. Were their actions those that a black comrade would find laudable? Would trust? The Daily Worker noted that "Every member of the Party must bear in mind" the bitterness and distrust of the oppressed, colonized, and weak masses toward the proletariat of oppressor nations" ("Black Belt Thesis" 2018: 288). The Party undertook focused work to confront white chauvinism - a campaign of self-criticism, the cultivation of black leaders, mass public trials, expulsions. It amped up its organizing and recruitment among African Americans. It engaged in what Solomon calls "a frenzy of struggle for equality and black liberation" (1998: 87). Some organizers in the US South "criticized purges of racially prejudiced whites" (Solomon 1998: 128). The Party took the view, however, that even if the effect was political isolation in the South any concession to segregation "would validate racism and sacrifice blacks' trust in white radicals” (Solomon 1998: 128).

The comrade is a generic figure for the political relation between those on the same side. It is characterized by sameness, equality, and solidarity. But what does this mean under conditions of racial capitalism, of a capitalism anchored in white supremacy? It means the active confrontation with and rejection of these conditions in a recomposition of equality and solidarity. The CP's commitment to black self-determination in the Black Belt exemplifies this sort of comradeship. It was utopian, a scandalous insistence that a large area of the Southern United States belongs to African Americans because they built it, their work made it, and their historic experience of capture, in the hold, under the lash, reenslavement, lynching and Jim Crow engendered a national psychology that expresses itself as a collective longing for freedom. The Black Belt slogan refuses to let this experience and this longing be subordinate to class struggle or reduced to the abolition of discrimination. The whole Jim Crow capitalist system had to come down.

Just as the miscellaneous remaindered others of Chevegur are a deracinated heap, so does the political investment in black liberation struggle the CP demanded of white workers posit a zero-level of belonging: race does not determine who is a comrade. Such a demand enjoins the abolition of white chauvinism, white privilege. For a while, the $\mathrm{CP}$ was feverishly invested in this process, in ways that sometimes "degenerated into fantastic accusations" and in ways that were sometimes manipulated in intra-party machinations. It also happened that the frequent and repeated accusations, trials, and expulsions gave rise to the sense that racism would never be eradicated from the Party (Solomon 1998: 144-45). The intense longing for justice, the enthusiasm comrades brought to the struggle for black liberation, inspired a critical impulse that turned in on 
itself with a ferocity that exposed comradeship as an impossible ideal. Some criticize the Party for its inability to eradicate racism, "white chauvinism," from its ranks. This criticism can never reach the intensity of the critique the Party waged against itself.

The very intensity of this critique, however, draws out the indispensable negativity of "comrade." As the zero-level of communism, comradeship is what we have when we have nothing else. It is the degree of sociality necessary to persevere, to go on. For the CPUSA, commitment to a defense of black life and black land, even to the point of self-destruction, was necessary if the Party was to continue as a party for all the workers, that is, as a communist party.

\section{Conclusion}

Comradeship is a glorious ideal. It summons a longing for equality, solidarity, for a political intimacy and trust that seems impossible. The negativity in Platonov's presentation of comrades in a joyless condition of rupture, possibility, longing, and loss both diminishes the cheerful anticipation of comradeship and highlights its necessity: perseverance requires others; it can't be done alone. One might accept this reading of Platonov but nevertheless object to its extension to the racial dilemmas of the CPUSA. Is it not the case that Platonov's comrades have no race or nation, birth or class? How is affirming a nation reconcilable with this view? I have emphasized not that such statuses don't exist but that the comrade enables the status given by the world to be combatted, effaced, even overcome. Comradeship negates these statuses and so constitutes a zero-level of communism. For white communists, this demands a willingness to die for the black liberation struggle, to forfeit white privilege, eliminate white supremacy, even if this means destroying the Party. It means embracing the counter-factual claim of black sovereign right to a land worked by African Americans - even when the majority of African Americans don't appear to be making this claim. The outrageous scandal of the Black Belt thesis is in its rejection of the two basic approaches to the "Negro question" in the United States: immigration or assimilation. In the late nineteenth and early twentieth century, most black political organizing emphasized one or the other. The Communists offered a third path: national self-determination, that is, the ceding of US territory and white supremacy across several states in the US south. Black comrades already inhabited a position of violent deprivation and social death, Jim Crow and lynch law. ${ }^{12}$ The wager of comradeship - we can call

12 On black social death, see Wilderson, Spatzek, and von Gleich (2016). 
it Briggs's wager - is that if white people are willing to put their lives on the line in the struggle for black liberation, then black people's own interest in communism should lead them all to be comrades. Comrades are the zero-level of sociability necessary for communism.

\section{References}

Bartholmes, Herbert (1970). Bruder, Bürger, Freund, Genosse. Gothenburg: Acta Universitatis Gothoburgensis.

“Black Belt Thesis” (2018). In Class Struggle and the Color Line, ed. Paul M. Heideman, 283-90. Chicago: Haymarket Books.

Briggs, Cyril V (2018a). “Bolshevism and Race Prejudice.” In Class Struggle and the Color Line, ed. Paul M. Heideman, 241. Chicago: Haymarket Books.

Briggs, Cyril V (2018b). “The Acid Test of White Friendship.” In Class Struggle and the Color Line, ed. Paul M. Heideman, 263-64. Chicago: Haymarket Books.

Chehonadskih, Maria (2017). "Soviet Epistemologies and the Materialist Ontology of Poor Life,” PhD Diss. Centre for Research in Modern European Philosophy, Kingston University, UK.

Garo, Isabelle (2017). "Chevengur, the Country of Unreal Communism - The October Revolution Through the Dialectical Art of Andréi Platonov." Crisis and Critique 4.2: $174-96$.

Gorky, Maxim (1905). “Comrade.” The Social Democrat X.8: 509-12. Marxist Internet Archive. https://www.marxists.org/archive/gorky-maxim/1906/08/comrade.htm.

Haywood, Harry (1978). Black Bolshevik: Autobiography of an Afro-American Communist. Chicago: Liberator Press.

Jameson, Fredric (1994). The Seeds of Time. New York: Columbia University Press.

Kollontai, Alexandra (1977a). "Communism and the Family" [1920]. In Selected Writings of Alexandra Kollontai, trans. Alix Holt. Marxist Internet Archive. https://www. marxists.org/archive/kollonta/1920/communism-family.htm

Kollontai, Alexandra (1977b). "Sexual Relations and the Class Struggle” [1921]. In Selected Writings of Alexandra Kollontai, trans. Alix Holt. Marxist Internet Archive. https://www.marxists.org/archive/kollonta/1921/sex-class-struggle.htm

Kollontai, Alexandra (2006). "New Woman” [1918]. In The New Morality and the Working Class trans. Salvator Attansio. Marxist Internet Archive. https://www.marxists. org/archive/kollonta/1918/new-morality.htm

Magun Artemy (2013). Negative Revolution. London: Bloomsbury.

Platonov, Andrei (1978). Chevengur. Trans, Anthony Olcott. Ann Arbor, MI: Ardis Publishers.

Podoroga, Valery (1991). “The Eunuch of the Soul.” South Atlantic Quarterly 90: 2: 357407.

Robinson, Cedric J. (2000). Black Marxism. Chapel Hill, NC: University of North Carolina Press.

Sitas, Ari (1992). “The Making of the 'Comrades’ Movement in Natal, 1985-1991.” 18. 3: 
629-41.

Solomon, Mark (1998). The Cry Was Unity. Jackson: University of Mississippi Press.

Tomek, Beverly (2012). "The Communist International and the Dilemma of the American "Negro Problem”: Limitations of the Black Belt Self-Determination Thesis.” WorkingUSA: The Journal of Labor and Society 15: 549-76.

Trotsky, Leon (1940). “On Black Nationalism: Documents on the Negro Struggle.” Marxist Internet Archive https://www.marxists.org/archive/trotsky/works/1940/ negro1.htm\#sd

Vinokur, G. O. (1929). Kul'tura iazyka [Language culture]. Moscow: Izdat. Federacija.

Wark, McKenzie (2015). Molecular Red. London: Verso.

Whitaker, Robert (2009). On the Laps of the Gods. New York: Three Rivers Press.

Wilderson, Frank Samira Spatzek, and Paula von Gleich (2016). "'The Inside-Outside of Civil Society': An Interview with Frank B. Wilderson, III.” Black Studies Papers 2.1: 4-22.

Žižek Slavoj (2013). Less Than Nothing. London: Verso. 